\title{
Analisis Biaya Pengobatan Pasien Diagnosa Demam Tifoid di Instalasi Rawat Inap RSUD Dr Soedarso Pontianak Tahun 2018
}

Heny Puspasari*, Dani Suryaningrat, Muhammad Rizky

Departemen Farmasi, Akademi Farmasi Yarsi, Pontianak, Indonesia

*Corresponding author: heny24puspasari@gmail.com

Submitted: 8 November 2019

Accepted: 17 Mei 2020

Published: 25 Juni 2020

\begin{abstract}
Background: Typhoid fever remains to be a digestive tract endemic disease in Indonesia. Since health care costs, especially medicine cost had increased sharply in recent decades, it is important to conduct cost of illness study including in typhoid disease to update cost information related to this illness to healthcare providers and policy makers. Objective: This study was aimed to determine the type of drug, the length of stay. and the cost of treatment patients in the hospital Dr. Soedarso. Method: Descriptive analysis assessing direct cost with retrospective data collection was conducted based on medical records and patient financial records. Results: The types of drugs that were widely used were thiamphenicol antibiotics in 8 patients $(19.51 \%)$ and cefixime in 6 patients (14.63\%). Inpatient with typhoid mostly spent 6 days in hospital (26.87\% of 41 patients), whilst the longest length of stay was 9 days (4.87\% of 41 patients). The biggest part of cost was hospitalization which was IDR 37,400,300 (41.90\% from total cost IDR 89,262,145) and the smallest cost was administition costs with IDR 5,323,000 (5.97\%). The average total treatment cost for patients with insurance (BPJS) was IDR 2,179,380. Meanwhile, the average cost of patients without insurance was IDR2,228,669. Conclusion: The average cost of treatment is still somewhat cheaper compared to the standard cost of treatment from the government for BPJS claims. The treatment used was in line with the therapeutic algorithm.
\end{abstract}

Keywords: cost analysis, treatment, typhoid fever

\begin{abstract}
Abstrak
Pendahuluan: Demam Tifoid merupakan penyakit saluran pencernaan yang endemik di Indonesia. Hal ini karena biaya perawatan kesehatan, terutama biaya obat-obatan telah meningkat tajam dalam beberapa dekade terakhir, sehingga penting untuk dilakukan studi biaya penyakit ini untuk memperbarui informasi terkait biaya kepada penyedia layanan kesehatan dan pembuat kebijakan. Tujuan: Penelitian ini untuk mengetahui jenis obat, lama waktu pengobatan, dan biaya pengobatan pasien demam tifoid di instalasi rawat inap RSUD Dr. Soedarso. Metode: Penelitian analisis deskriptif biaya langsung (direct cost) dengan pengambilan data retrospektif dilakukan berdasarkan data rekam medik dan catatan pembiayaan pasien. Hasil: Penelitian menunjukkan bahwa jenis obat yang paling banyak digunakan adalah golongan antibiotik tiamfenikol (8 pasien atau $19,51 \%$ ) dan cefiksime (6 pasien atau 14,63\%) dari 41 pasien. Kebanyakan pasien mendapat perawatan dengan lama 6 hari (26,87\% dari 11 pasien), dan waktu rawat inap terlama 9 (4,87\% dari 41 pasien). Komponen biaya terbesar adalah biaya rawat inap yaitu Rp. 37.400.300 dengan persentase 41,90 \% dari total biaya Rp. 89.262.145 dan biaya terkecil yaitu biaya administrasi yaitu Rp. 5.323.000 dengan persentase 5,97\% dari total biaya. Rata-rata biaya pengobatan per pasien BPJS Rp. 2.179.380 dan rata-rata biaya per pasien umum Rp. 2.228.669. Kesimpulan: Biaya pengobatan masih terbilang lebih murah dibandingkan dengan biaya pengobatan berdasarkan tarif dari pemerintah untuk klaim BPJS. Pengobatan yang digunakan juga sudah sesuai dengan algoritma terapi.
\end{abstract}

Kata kunci: analisis biaya, pengobatan, demam tifoid 


\section{PENDAHULUAN}

Demam tifoid merupakan penyakit endemik yang disebabkan oleh kuman Salmonella typhosa (Eberthella typhosa) yang merupakan jenis penyakit infeksi saluran pencernaan yang mengakibatkan peradangan pada bagian usus halus dan lumen usus (Etikasari dkk., 2012).

Biaya kesehatan beberapa waktu ini telah banyak menarik perhatian. Biaya pelayanan kesehatan yang khususnya menyangkut biaya obat telah mengalami peningkatan yang sangat signifikan beberapa tahun terakhir ini dan kecenderungan ini tampaknya akan terus berlangsung. Hal tersebut antara lain disebabkan oleh jumlah pasien yang semakin banyak, adanya perubahan pola pengobatan, sehingga konsekuensinya meningkatnya penggunaan obat, serta terdapat banyaknya obat-obat baru dengan harga lebih mahal (Kemenkes RI, 2006)

Penyakit demam tifoid masih merupakan masalah kesehatan di Kalimantan Barat. Menurut data survei terpadu Penyakit Provinsi Kalimantan Barat, untuk kasus tifoid pada tahun 2012 sebanyak 9.979 kasus, dengan sebaran penyakit di 12 kabupaten kota, 5 kota atau kabupaten dengan kasus tifoid terbanyak antara lain, Kabupaten Sanggau 2.914 (29,20\%), Kabupaten Sintang 2.434 (24,39\%), Kota Pontianak 1.169 (11,17\%), Kabupaten Melawi 1.067 (10,69\%), dan Kabupaten Pontianak 632 (6,33\%).

Jumlah penderita demam tifoid setiap tahunnya terus meningkat di Kota Pontianak. Berdasarkan laporan tahunan RSUD Dr. Soedarso Pontianak, pada tahun 2010 jumlah kasus baru rawat jalan dan rawat inap ada sebanyak 1.180 penderita dengan 4 orang meninggal dunia, tahun 2011 berjumlah 842 penderita dengan 5 orang meninggal dunia, tahun 2012 berjumlah 922 penderita dengan 2 orang meninggal dunia. Terbanyak penderita demam tifoid berumur 5 15 tahun dengan jumlah kasus sebanyak 539 penderita. Total jumlah kasus demam tifoid pada tahun 2012 menempati urutan kedua setelah diare (RSUD Dr. Soedarso, 2015).

Tahun 2013 jumlah kasus baru demam tifoid untuk rawat jalan dan rawat inap ada sebanyak 861 penderita dengan 4 orang meninggal dunia dan pada tahun 2014 dari bulan Januari sampai dengan April jumlah kasus demam tifoid ada sebanyak 150 kasus. Sama seperti tahun 2012 terbanyak penderita demam tifoid berumur 5 - 15 tahun dengan jumlah kasus sebanyak 421 penderita (RSUD Dr. Soedarso, 2015).

Berdasarkan atas biaya perawatan kesehatan, terutama biaya obat-obatan telah meningkat tajam dalam beberapa dekade terakhir, sehingga penting untuk dilakukan penelitian tentang "Analisis Biaya Pengobatan Pasien Diagnosa Demam Tifoid Di Instalasi Rawat Inap RSUD Dr. Soedarso Pontianak Periode Juli - Oktober Tahun 2018" ini untuk memperbarui informasi terkait biaya kepada penyedia layanan kesehatan dan pembuat kebijakan.

\section{BAHAN DAN METODE}

\section{Desain penelitian}

Penelitian ini merupakan jenis penelitian deskriptif dengan pengambilan data secara retrospektif yang didasarkan pada catatan rekam medik dan catatan pembiayaan.

\section{Tempat dan waktu penelitian}

Penelitian ini dilakukan di Bagian Keuangan dan Rekam Medik RSUD Dr. Soedarso Pontianak Kalimantan Barat pada bulan Januari 2019.

\section{Populasi dan sampel penelitian}

Populasi dalam penelitian ini adalah seluruh pasien rawat inap di RSUD Dr. Soedarso dengan diagnosa demam tifoid tanpa komplikasi berdasarkan kode di rekam medis Periode Juli - Oktober tahun 2018. Sampel penelitian yaitu bagian dari jumlah dan karakteristik yang dimiliki oleh populasi tersebut. Pada penelitian ini digunakan sampel jenuh. Sampel jenuh adalah teknik penentuan sampel bila semua anggota populasi digunakan sebagai sampel. Hal ini sering dilakukan bila jumlah populasi relatif kecil, kurang dari 30 orang, atau penelitian yang ingin membuat kesalahan yang sangat kecil (Sugiyono, 2016).

\section{Variabel penelitian}

Menurut Sugioyono (2016), variabel penelitian adalah segala sesuatu yang berbentuk apa saja yang ditetapkan oleh peneliti untuk dipelajari sehingga diperoleh informasi tentang hal tersebut. Pada penelitian ini variabel yang di teliti yaitu, sebagai berikut:

1. Jenis obat

2. Pasien

3. Umur pasien

4. Biaya langsung (direct cost)

5. Lama waktu rawat inap

6. Biaya obat

7. Biaya rawat inap

8. Biaya administrasi

9. Biaya laboratorium

10. Biaya visite dokter

\section{Teknik dan instrumen pengumpulan data}

Pada penelitian ini pengumpulan data atau pengambilan sampel penelitian dilakukan secara 
retrospektif dengan cara observasi langsung pada catatan rekam medis dan data keuangan pasien. Instrumen (alat) pengumpulan data yang digunakan dalam penelitian ini adalah dengan menggunakan formulir observasi atau tabel pengamatan.

\section{Teknik analisis data}

Data yang dihasilkan dianalisa secara deskriptif dengan menggunakan hasil data yang telah didapat pada rekam medis dan catatan pembiayaan.

\section{HASIL DAN PEMBAHASAN}

Jumlah pasien rawat inap demam tifoid pada periode Juli - Oktober tahun 2018 adalah 41 pasien, dengan pasien tertinggi pada bulan September dengan Jumlah 22 pasien dan pasien terendah pada bulan Agustus 5 pasien. Jumlah pasien demam tifoid dari bulan Juli sampai Oktober tahun 2018 sangat fluktuatif dengan hasil yang berbeda setiap bulan-nya.

Penyakit demam tifoid lebih banyak diderita oleh laki-laki dengan persentase $58,53 \%$. Laki-laki memiliki aktivitas yang lebih tinggi dari pada perempuan
(Nadyah, 2014). Aktivitas lebih tinggi dapat menimbulkan stress, yang berperan terhadap kualitas hidup seseorang.

Berdasarkan hasil penelitian diperoleh bahwa jenis obat antibiotik yang banyak digunakan oleh pasien demam tifoid di RSUD Dr. Soedarso Pontianak yaitu pasien banyak menerima terapi antibiotik jenis tiamfenikol sebanyak $19,51 \%$ (8 pasien). Antibiotik tiamfenikol adalah jenis antibiotik turunan dari kloramphenicol yang juga aktif terhadap bakteri Salmonella typhosa. Pada trilogi penatalaksanaan demam tifoid, pemberian antimikroba yang sering digunakan adalah kloramfenikol dan tiamfenikol (Widodo, 2006). Terapi pasien demam tifoid terbanyak selanjutnya yaitu jenis antibiotik cefiksime sebanyak $14,63 \%$ (6 pasien). Cefiksime ialah jenis antibiotik golongan sefalosporin generasi ketiga, antibiotik ini mempunyai aktifitas antimikroba yang baik terhadap bakteri gram negatif Salmonella typosa sehingga merupakan obat terapi yang baik untuk pengobatan penyakit demam tifoid (Haluang dkk., 2015).

Tabel 1. Biaya langsung (direct cost) pasien BPJS dan umum di instalasi rawat inap RSUD Dr. Soedarso Pontianak dengan diagnosa demam tifoid periode Juli - Oktober tahun 2018

\begin{tabular}{lccc}
\hline \multirow{2}{*}{ Jenis biaya langsung } & \multicolumn{3}{c}{$\mathrm{N}=41$} \\
\cline { 2 - 4 } Administrasi & Jumlah biaya & Biaya perpasien & Persentase biaya rata-rata \\
\hline Laboratorium & Rp. 5.323 .000 & Rp. 129.829 & $5,96 \%$ \\
Obat & Rp. 10.828 .811 & Rp. 264.117 & $12,13 \%$ \\
Rawat inap & Rp. 20.322 .388 & Rp. 495.668 & $22,77 \%$ \\
Visite dokter & Rp. 37.400 .300 & Rp. 912.202 & $41,90 \%$ \\
Total & Rp. 15.387 .646 & Rp. 375.308 & $17,24 \%$ \\
\hline
\end{tabular}

Keterangan: Persentase biaya rata-rata merupakan persentase jumlah biaya pada setiap jenis biaya langsung untuk semua pasien dibandingkan total biaya langsung untuk semua pasien

Berdasarkan Tabel 1 di atas menjelaskan bahwa biaya langsung (direct cost) yang dikeluarkan oleh pasien dengan diagnosa demam tifoid biaya terbesar yang dikeluarkan adalah biaya rawat inap dan biaya terkecil adalah jenis biaya administrasi dari total keseluruhan biaya langsung yang dikeluarkan oleh tiap-tiap pasien di rumah sakit ini. Jenis biaya ini sama untuk tiap-tiap pasien baik dengan status tanggungan BPJS maupun umum.

Tabel 2. Biaya langsung (direct cost) pasien BPJS di instalasi rawat inap RSUD Dr. Soedarso Pontianak diagnosa demam tifoid periode Juli - Oktober tahun 2018

\begin{tabular}{lccc}
\hline \multirow{2}{*}{ Jenis biaya } & \multicolumn{3}{c}{$\mathrm{N}=35$} \\
\cline { 2 - 4 } & Jumlah biaya & Biaya perpasien & Persentase biaya rata-rata \\
\hline Administrasi & Rp. 4.405 .000 & Rp. 129.857 & $5,81 \%$ \\
Laboratorium & Rp. 8.812 .913 & Rp. 251.797 & $11,61 \%$ \\
Obat & Rp. 18.562 .259 & Rp. 530.350 & $24,46 \%$ \\
Rawat inap & Rp. 30.613 .300 & Rp. 874.665 & $40,34 \%$ \\
Visite dokter & Rp. 13.496 .146 & Rp. 385.604 & $17,78 \%$ \\
Total & Rp. 75.889 .618 & Rp 2.168.274 & $100 \%$ \\
\hline
\end{tabular}

Keterangan: Persentase biaya rata-rata merupakan persentase jumlah biaya pada setiap jenis biaya langsung untuk semua pasien dibandingkan total biaya langsung untuk semua pasien. 
Tabel 2 di atas menjelaskan bahwa biaya langsung (direct cost) yang dikeluarkan oleh pasien tifoid dengan status tanggungan BPJS. Jenis biaya terbesar yang dikeluarkan adalah biaya rawat inap dan biaya terkecil adalah jenis biaya administrasi dari total keseluruhan biaya langsung yang dikeluarkan oleh tiap-tiap pasien di rumah sakit ini. Biaya obat-obatan untuk pasien masih terbilang terjangkau dimana biaya obat menempati biaya kedua tertinggi setelah biaya rawat inap. Jenis obat yang digunakan sesuai dengan tatalaksana terapi yang sesuai dengan algoritma, yang mana pada tatalaksana jenis obat yang banyak digunakan adalah antibiotik tiamfenikol dan cefiksime. Hal ini juga sesuai dengan Widodo (2006) pemberian antimikroba yang sering digunakan dalam trilogi terapi demam tifoid adalah kloramfenikol, tiamfenikol, kotrimoksazol, ampisilin dan amoksisilin, sefalosporin generasi ketiga, golongan fluorokuinolon, dan kortikosteroid.

Tabel 3. Biaya langsung (direct cost) pasien umum (tanpa asuransi) di instalasi rawat inap RSUD Dr. Soedarso Pontianak diagnosa demam tifoid periode Juli - Oktober tahun 2018

\begin{tabular}{lccc}
\hline \multirow{2}{*}{ Jenis biaya langsung } & \multicolumn{3}{c}{$\mathrm{N}=6$} \\
\cline { 2 - 4 } & Jumlah biaya & Biaya perpasien & Persentase biaya rata-rata \\
\hline Administrasi & Rp. 917.500 & Rp. 152.916 & $6,86 \%$ \\
Laboratorium & Rp. 2.015 .598 & Rp. 335.933 & $15,07 \%$ \\
Obat & Rp. 1.760 .129 & Rp. 293.354 & $13,16 \%$ \\
Rawat inap & Rp. 6.787 .000 & Rp. 1.131 .166 & $50,76 \%$ \\
Visite dokter & Rp. 1.891 .500 & Rp. 315.250 & $14,15 \%$ \\
Total & Rp. 13.371 .727 & Rp 2.228.621 & 100 \\
\hline
\end{tabular}

Keterangan: Persentase biaya rata-rata merupakan persentase jumlah biaya pada setiap jenis biaya langsung untuk semua pasien dibandingkan total biaya langsung untuk semua pasien.

Tabel 3 di atas menjelaskan bahwa biaya langsung (direct cost) yang dikeluarkan oleh pasien tifoid dengan status tanggungan umum jenis biaya terbesar yang dikeluarkan adalah biaya rawat inap dan biaya terkecil adalah jenis biaya administrasi dari total keseluruhan biaya langsung yang dikeluarkan oleh tiap-tiap pasien di rumah sakit ini. Biaya terbesar kedua adalah jenis biaya laboratorium, hal ini berbeda dengan pasien BPJS dimana biaya terbesar kedua adalah biaya obat. Pada pasien umum jenis biaya obat juga masih terbilang terjangkau dimana biaya obat menempati biaya tertinggi ketiga. Hal ini dapat dikarenakan jenis obat yang digunakan juga masih relatif sama dengan jenis obat yang digunakan oleh pasien dengan status tanggungan BPJS.

Tabel 4. Perbandingan total biaya pengobatan pasien di instalasi rawat inap RSUD Dr. Soedarso Pontianak diagnosa demam tifoid periode Juli - Oktober tahun 2018

\begin{tabular}{lccc}
\hline \multirow{2}{*}{ Jenis biaya langsung } & \multicolumn{3}{c}{$\mathrm{N}(\mathrm{BPJS})=35, \mathrm{~N}($ Umum) $=6$} \\
\cline { 2 - 4 } & Jumlah biaya & Biaya perpasien & Persentase biaya rata-rata \\
\hline Biaya pasien BPJS & Rp. 75.889 .618 & Rp. 2.168.274 & $49,31 \%$ \\
Biaya pasien umum & Rp. 13.371 .727 & Rp. 2.228 .621 & $50,69 \%$ \\
Total & Rp. 89.262.145 & Rp 4.408.049 & 100 \\
\hline
\end{tabular}

Keterangan: Persentase biaya rata-rata merupakan persentase jumlah biaya pada setiap jenis biaya langsung untuk semua pasien dibandingkan total biaya langsung untuk semua pasien.

Total biaya langsung (direct cost) demam tifoid pada Tabel 4 diatas berdasarkan hasil yang didapat di RSUD Dr. Soedarso periode Juli - Oktober tahun 2018 pada penelitian ini adalah Rp. 89.262.145 yang dimana penjumlahan dari total biaya pasien umum rawat inap sebesar Rp. 13.371.727 dengan biaya per pasien Rp. 2.228.621 (50,69\%) dengan jumlah pasien umum 6 orang pasien, untuk total biaya rawat inap pasien BPJS sebesar Rp. 75.889 .618 dengan biaya per pasien Rp. 2.168.274 persentase (49,31\%) sebanyak 35 pasien BPJS, dengan demikian perbedaan yang terdapat pada jumlah biaya keseluruhan demam tifoid disini adalah jumlah pasien yang berbeda jauh antara pasien BPJS dan pasien Umum. Perbedaan nilai rata-rata total biaya rawat inap pasien umum (tanpa ansuransi) dan BPJS ini juga dapat juga disebabkan karena banyaknya variasi jumlah biaya dan rawat inap pada setiap pasien. Dari hasil penelitian Tabel 4 di atas, total biaya per pasien demam tifoid di RS. Soedarso yaitu sebesar Rp. 2.177.125 per pasien dengan biaya inap memakan biaya terbesar yaitu Rp. 912.202. Dengan adanya biaya yang masih ditanggung oleh pasien sebanyak 
Rp. 2.177.125, tampaknya keseimbangan peningkatan subsidi pemerintah belum mencukupi dan perlu dikaji kembali dalam penentuan besarnya subsidi untuk beberapa tahun selanjutnya. Adanya krisis ekonomi pada tahun ini sangat dirasakan oleh pasien yang tergolong kurang mampu. Biaya rawat inap lebih mahal dibandingkan dengan biaya obat pasien yang lebih murah yaitu Rp. 495.668 per pasien untuk kasus demam tifoid.

Biaya jasa dokter disini merupakan biaya yang diberikan kepada dokter sebagai imbalan atas pemeriksaan dalam menetapkan diagnosa pada pasien. Rata-rata biaya jasa dokter pada penyakit demam tifoid ini yaitu sebesar Rp. 375.308 sedangkan untuk rata-rata pada biaya administrasi disini sedikit lebih rendah dari pada jasa dokter yaitu sebesar Rp. 129.829.

Berdasarkan besaran standar tarif pelayanan kesehatan dalam penyelenggaraan program jaminan kesehatan nasional (JKN), biaya pasien diagnosa demam tifoid yang harus ditanggung perpasien yaitu sebesar Rp. 2.168.274. Rumah Sakit di Kalimantan Barat masuk kedalam regional tiga berdasarkan data dari Kemenkes RI (2014) dan RSUD Dr. Soedarso (2015) adalah golongan rumah sakit tipe B yang memiliki tiga jenis kelas yaitu kelas satu, dua, dan tiga. Biaya tarif yang ditanggung BPJS yaitu Rp. 6.614.500 (Kemenkes RI, 2014) pada tarif kelas 1. Dari hasil penelitian ini didapat bahwa biaya rata-rata per pasien untuk demam tifoid yaitu Rp. 2.168.274 dimana pasien RSUD Dr. Soedarso Pontianak masih memiliki keuntungan dari tunjangan BPJS tersebut, Selain itu, terapi pengobatan yang diberikan sesuai dengan tatalaksana terapi tifoid yaitu pemberian antimikroba yang sering digunakan salah satunya tiamfenikol dan sefalosporin generasi ketiga (Soedarmo dkk., 2008). Berdasarkan penelitian ini dapat dikatakan bahwa biaya pengobatan masih terbilang berada dibawah tarif ketentuan dari pemerintah, Pada penelitian (Yunita dkk., 2018) yang menyatakan bahwa pembiayaan pasien demam tifoid, membutuhkan terapi yang mampu mengatasi infeksi Salmonella typhi. Terapi yang digunakan untuk demam tifoid meliputi terapi simtometik dan antibiotik. Dari penelitian ini didapat pembayaran pasien Jaminan Kesehatan Nasional (JKN) yang menggunakan antibiotik seftriakson lebih rendah, yaitu sebesar Rp 1.866.525 per pasien.

\section{KESIMPULAN}

Penggunaan obat yang banyak digunakan pada kasus demam typhoid di RSUD Dr. Soedarso yaitu golongan antibiotik cefiksim dan tiampenikol, dengan waktu rawat inap pasien paling lama adalah 9 hari, biaya terbesar adalah biaya rawat inap, dan biaya terkecil yaitu biaya administrasi. Biaya pengobatan ini masih terbilang lebih rendah dengan biaya pengobatan masih berada dibawah tarif ketentuan pemerintah untuk klaim BPJS.

\section{DAFTAR PUSTAKA}

Etikasari R, Andayani, T. M. \& Mukti, A. G. (2012). Analisis Biaya dan Kesesuaian Penggunaan Antibiotik pada Demam Tifoid di RSUD Kota Yogyakarta. Jurnal Manajemen dan Pelayanan Farmasi; 2; 147-153.

Haluang, O., Tjitrosantoso, H. \& Kojong, N. S. (2015). Analisis Biaya Penggunaan pada Penderita Demam Tifoid Anak di Instalasi Rawat Inap Rsup Prof. Dr. R. D. Kandou Manado Periode Januari 2013 - Juni 2014. Pharmacon Jurnal Ilmiah Farmasi; 4; 117-125.

Kemenkes RI. (2014). Permenkes RI No 59 Tentang Standar Tarif Pelayanan Kesehatan dalam Penyelenggaraan Program Jaminan Kesehatan. Jakarta: Kementerian Kesehatan Republik Indonesia.

Kemenkes RI. (2006). Keputusan Menteri Kesehatan RI Nomor 364/Menkes/SK/V/2006 Tentang Pedoman Pengendalian Demam Tifoid. Jakarta: Kementerian Kesehatan Republik Indonesia.

Nadyah. (2013). Hubungan Faktor-faktor yang Mempengaruhi Insidens Penyakit Demam Tifoid Di Kelurahan Samata Kecamatan Somba OPU Kabupaten Gowa 2013. Jurnal Kesehatan UIN Alaudin Makasar; 7; 305-321.

RSUD Dr. Soedarso. (2015). Profil RSUD Dr. Soedarso. http:// www.rsudsoedarso.com/2015/01/rumah-sakitdaerah-doktersoedarsopontianak. Accessed: 13 September 2017.

Soedarmo, S. S. P., Garna, H., Hadinegoro, S. R. S., Satari, H. I., Dokter, I. \& Indonesia, A. (2008). Buku Ajar lnfeksi dan Pediatri Tropis Edisi Kedua IDAI. Jakarta: Ikatan Dokter Anak Indonesia.

Sugiyono. (2016). Metodologi Penelitian Kuantitatif Kualitatif dan R\&D. Bandung: Penerbit Alfabeta. Widodo, J. (2006). Demam Tifoid, Buku Ajar Ilmu Penyakit Dalam. Jakarta: Pusat Penerbitan Departemen Ilmu Penyakit Dalam FKIU.

Yunita, W. C., Pramestutie, H. R., Illahi, R. K. \& Achmad, A. (2018). Analisis Cost-Minimization Penggunaan Sefotaksim, Seftriakson dan 
Levofloksasin pada Pasien Demam Tifoid dengan

Status Pembayaran Umum dan Jaminan Kesehatan Nasional: Penelitian dilaksanakan di Rumah Sakit Daerah Kanjuruhan Kepanjen.

Pharmaceutical Journal of Indonesia; 4; 11-15. 